\title{
Greenlandic schoolchildren's compliance with national dietary guidelines
}

\author{
Birgit Niclasen ${ }^{1,2, *}+$ and Christina W Schnohr ${ }^{3}$ \\ ${ }^{1}$ Greenland Institute of Health Research, Nuuk, Greenland: ${ }^{2}$ Nordic School of Public Health, Gothenburg, \\ Sweden: ${ }^{3}$ Department of Social Medicine, Institute of Public Health, University of Copenhagen, \\ Copenhagen, Denmark
}

Submitted 11 December 2008: Accepted 1 November 2009: First published online 17 December 2009

\begin{abstract}
Objective: The aim of the present study was to examine to what extent children and adolescents in Greenland comply with the national dietary guidelines, and to analyse the influence of habitation and family affluence on the compliance with dietary guidelines.

Design: Data were from the Health Behaviour in School-aged Children (HBSC) survey in Greenland. The 2006 survey included 2462 students aged 11 to 17 years. Results: The proportion of students complying with the national dietary guidelines varied from $14 \%$ to $87 \%$ depending on the food item. Sweets and soft drinks had the lowest compliance. The oldest children had the following characteristics compared with the younger children: fewer ate traditional Greenlandic foods, fewer ate fruit, fewer ate breakfast daily on school days and more drank soft drinks frequently. More boys than girls ate traditional Greenlandic foods often, while more girls ate vegetables daily. The least favourable eating habits in general were found among children from low affluent families and children in villages. Conclusions: Many Greenlandic schoolchildren did not comply with the national dietary guidelines. Despite a higher intake of traditional foods as a whole, children in villages and less affluent children were less likely to comply with guidelines. A strong relationship between diet, family affluence and availability was found. The study findings indicate that factors such as availability, cost and seasonal variation are important to the intake of both imported and traditional Greenlandic foods. The findings should be taken into consideration when promoting the national guidelines.
\end{abstract}

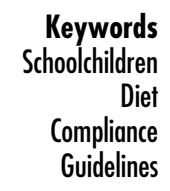

Most countries have policies on nutrition and food safety, and general recommendations to the public on a healthy diet. Despite these public guidelines the burden of disease associated with poor nutrition continues to grow worldwide $^{(1)}$, and Greenland is no exception.

Greenland is located in the Arctic region. It is the largest island in the world. People live on the coastline only because the large central icecap covers most of the island. The population is 57000 inhabitants of whom $30 \%$ are children below 18 years of age. About $90 \%$ of the population is of Inuit origin. The Inuit in Greenland have a distinct culture, and language and diet are unique and central markers of Greenlandic culture ${ }^{(2)}$. Greenland has seventeen small cities and sixty villages scattered along the coastline. The habitations are connected by boat or plane only. A more traditional lifestyle and getting a living from smallscale fishing and hunting are generally seen in the villages.

$†$ Correspondence address: PO Box 7011, 3905 Nuussuaq, Greenland.
The economic conditions in villages are generally more unfavourable than those found in nearby towns.

Diseases related to diet and other lifestyle conditions such as overweight and diabetes are among the fastest growing diseases in the $\mathrm{Arctic}^{(2)}$. The epidemic of obesity has also reached Greenland ${ }^{(3-5)}$ and type 2 diabetes is beginning to show in the child population. During the past 25 years, overweight in children has increased threefold. Today, nearly $25 \%$ of schoolchildren in the first grade have been found overweight or obese. In addition, the age when reaching overweight has continued to decrease, and early acquired overweight has been found to track into adolescence in a majority of children ${ }^{(3-5)}$.

\section{Diet in the Greenlandic context}

The traditional Greenlandic diet is based primarily on meat and blubber from marine mammals, providing a diet rich in protein and fat including only a small amount of carbohydrate. The local foods play an important role 
socially and culturally, and are regarded as being healthier than imported foods.

Globalization of the human diet is an area of growing importance, not least in Greenland. As a country in societal transition, rapid changes in dietary habits and a process of a fast 'nutritional transition' have been seen ${ }^{(6)}$. This development has led away from a high intake of traditional and locally derived foods towards a more Westernized diet, with increased use of imported food items. Imported foods provide approximately $75 \%$ of the energy consumed $^{(7)}$, but local variation exists. Today, the recommended energy distribution from macronutrients is the same as in other Nordic countries (55-60\% from carbohydrates, 10-15\% from protein, no more than $30 \%$ from fat $)^{(8)}$. Among adults, the energy distribution is close to the recommendation including approximately $20 \%$ from protein and 33\% from fats ${ }^{(8)}$. The energy distribution in Greenlandic children has not been investigated. Still one result of the rapid dietary transition is large differences in food choices between young and old as the use of traditional and local foods has decreased, especially in young adults ${ }^{(9,10)}$.

Access to imported foods, especially fresh fruit and vegetables, is highest and prices lowest in the capital and the larger cities. The traditional and local foods are often self-supplied and self-supply of local foods is more common in the villages and more remote areas ${ }^{(9,10)}$. Some berries grow along most of the coastline, while potatoes and a few vegetables are grown in southern Greenland.

In 2006, the Greenlandic Board of Nutrition launched nine general dietary recommendations to the public. In general, these are very similar to recommendations in other Nordic and European countries and those of $\mathrm{WHO}^{(1)}$, with the exception that the Greenlandic advice includes intake of traditional local foods. These are fish and meat from seal, whale, polar bear, musk ox, birds, reindeer and lamb. Lamb is herded only in southern Greenland. These unique recommendations are balancing the dilemma between the positive health effects of the traditional diet of especially marine mammals, and the pollution of these items by the concentration of potentially harmful persistent organic pollutants (primarily polychlorinated biphenyls), pesticides and heavy metals in the marine food chain. This pollution is a threat to the traditional lifestyle and diet. In children, these pollutants have potential negative effects on neurophysiological development, certain hormones and the immune system $^{(11,12)}$. Nutrition is included as a focus area in the present public health programme in Greenland ${ }^{(13)}$.

A healthy diet is not only a choice between imported and local foods, it depends strongly on the composition of the mixed diet ${ }^{(6)}$ and the quality of both imported and local foods. Future strategies regarding dietary recommendations to the young Greenlandic population must build on the success of the present strategy.

The aim of the current study was to examine to what extent children and adolescents in Greenland comply with the current dietary guidelines, and to analyse the influence of habitation and family affluence on the compliance with dietary guidelines.

\section{Material and methods}

\section{National guidelines and derived objectives}

It was possibly to secure data to an operationalization of eight of the ten national dietary guidelines (Table 1). The most important dietary items without data were brown bread (which was excluded) and home-made meals (instead frequently eating precooked dinners was measured).

1. Vary your diet. To vary the diet is considered the most important of all the recommendations due to the potential negative health effects of a high intake of pollutants through dietary intake of marine mammals, polar bear (caught only in north and east Greenland), and to some extent wild birds, due to the lead content. Special guidelines on the intake of traditional foods exist with regard to children. In the current study, variation was defined as less than four meals per week including seal meat, or four including wild fowl, or four including whale meat.

2. Eat Greenlandic foods, eat fish often was divided into three objectives: (i) eating marine mammals (seal or whale) between one and three times weekly; (ii) eating local terrestrial animals (reindeer, musk ox or lamb) at least once weekly or birds between one and three times weekly; and (iii) eating fish at least once weekly.

3. Eat fruit and vegetables daily was defined as once or several times daily.

4. Eat potatoes often was defined as at least once weekly.

5. Eat less candy was defined as once weekly or less.

6. Drink syrup and soft drinks only for special occasions was defined as soft drinks with sugar once weekly or less.

7. Breakfast is the best start on the day was defined as eating breakfast every day on schooldays.

8. Eat a home-made hot meal every day was not included, instead eating precooked dinners four times weekly or more often was used.

Table 1 The general Greenlandic food recommendations

\begin{tabular}{ll}
\hline Operationalized & Vary your diet \\
& Eat Greenlandic foods, eat fish often \\
& Eat fruit and vegetables daily \\
& Eat brown bread, hulled grains every day. \\
Eat potatoes, rice or pasta often \\
Eat less sugar, candy, chips and cakes \\
Drink water. Drink syrup and soft drinks \\
only for special occasions \\
Eat often, but not much. Breakfast is the \\
best start on the day \\
Make dinner the family gathering. Eat a \\
home-made hot meal every day \\
Eat fat with care \\
Be physically active at least one hour a day
\end{tabular}


Data were from the Health Behaviour in School-aged Children (HBSC) survey in 2006 including children aged 11 to 17 years (grades 6 to 11). HBSC is a cross-national survey on child and adolescent health and health behaviour that collects data from forty countries and regions in Europe, North America and Israel. It is performed every four years ${ }^{(14)}$. The data set included 2462 students, corresponding to more than $40 \%$ of all Greenlandic schoolchildren in grades 6 to 11 . The participation rate in the participating schools was $67 \%{ }^{(15)}$. The survey included questions on food frequency originally developed for the HBSC questionnaire ${ }^{(16)}$ and for the Greenlandic health survey in $1993 / 4^{(9)}$.

The HBSC included the following questions.

1. 'How often do you eat...?' asked for seal, whale, wild birds, fish, reindeer, musk ox, hare, lamb, potatoes and precooked dinners (e.g. spring rolls, canned foods), with the response categories: 'every day', '4-6 times a week', '1-3 times a week', '2-3 times a month', ' 1 time a month or less' and 'never'.

2. 'How many times a week do you usually eat or drink...?' asked for fruits, vegetables, sweets (candy or chocolate) and coke or other soft drinks that contain sugar, with the response categories: 'never', 'less than once a week', 'once a week', '2-4 days a week', '5-6 days a week', 'once a day', 'every day' and 'every day, more than once'.

3. 'How often do you usually have breakfast (more than a glass of milk or fruit juice)?' with the response categories: 'I never have breakfast during weekdays', 'one day', 'two days', 'three days', 'four days' and 'five days'.

\section{Habitation}

The child's place of living was included as a measure of the general local availability of foods. The living place was categorized into Nuuk (the capital), towns and villages. The proportion of participants in the capital, towns and villages was $21 \cdot 6 \%, 58 \cdot 6 \%$ and $19 \cdot 8 \%$, while the proportion of the child population was $22 \cdot 6 \%, 58 \cdot 1 \%$ and $19 \cdot 3 \%$, respectively. Town status depended not only on having 1000 inhabitants or more, but also on having the local hospital and the administrative and educational centre.

\section{Family affluence}

The family's affluence was measured by the Family Affluence Scale (FAS) developed by Currie et $a l^{(17)}$. Several studies have shown that FAS is a valid measure of the family's socio-economic position ${ }^{(17)}$. FAS includes four items on material assets in the family: own bedroom (yes, no), family car (none, one or more), number of computers (none, one, several) and holidays during the past year (none, one, several). FAS was categorized into three levels, high (scores 6-7), medium (scores 3-5) and low (scores $0-2)^{(15)}$. Students with missing information on FAS $(10 \cdot 1 \%)$ were excluded from the analysis. Of the remaining participants, $20 \cdot 3 \%$ had low FAS, $30 \cdot 3 \%$ had medium FAS and $49 \cdot 5 \%$ had high FAS.

\section{Statistical analysis}

Statistical analyses were performed using the SPSS statistical software package version $15 \cdot 0$ (SPSS Inc., Chicago, IL, USA) using the $\chi^{2}$ test and multiple logistic regression. The regression analyses included three steps: (i) multiple logistic regression analysis with each of the dichotomous diet items as outcome measures and place of living as an independent variable (Model 1); (ii) Model 1 adjusted for age and gender (Model 2); and (iii) Model 2 adjusted for FAS (Model 3). The analyses in Model 1 were repeated stratified by gender, age group and FAS.

\section{Results}

\section{Proportion of students complying with national dietary guidelines}

The proportion of students complying with the national dietary guidelines varied from $14 \%$ to $87 \%$ depending on the food item (Table 2).

Diet variation. A mean of $87 \cdot 0 \%$ had a varied intake of local meats, but a smaller proportion of the younger children $(P<0 \cdot 001)$, low FAS children $(P<0 \cdot 001)$ and children in villages $(P<0 \cdot 001)$ had a varied diet.

Intake of marine mammals. Marine mammals were eaten one to three times weekly by $31.6 \%$, although by a higher proportion of boys than girls $(P=0 \cdot 01)$, of low FAS children $(P<0 \cdot 001)$ and of village children $(P<0 \cdot 001)$.

Intake of local terrestrial animals and birds. While mean of $37 \cdot 1 \%$ of children ate local terrestrial animals at the recommended level, a lower proportion was found in the older children $(P<0 \cdot 001)$ and a higher proportion in high FAS children $(P<0 \cdot 04)$.

Fish at least once weekly. A mean of $31 \cdot 8 \%$ had a weekly intake of fish, but the proportion with a weekly intake was higher in the youngest children $(P<0 \cdot 001)$, low FAS children $(P<0 \cdot 001)$ and children in villages $(P<0 \cdot 001)$.

Daily fruit. Only $14 \cdot 3 \%$ of children ate fruit every day, but a higher percentage of the youngest children $(P<0 \cdot 001)$ and children in the capital $(P<0 \cdot 001)$ consumed fruit daily.

Daily vegetables. Vegetables were eaten daily by $38.9 \%$ of the children; whereas a higher proportion of girls $(P<$ $0 \cdot 001)$ ate eat vegetables daily, a lower proportion of village children $(P=0.004)$ and low FAS children $(P=0 \cdot 006)$ were daily consumers.

Potatoes weekly or more often. A mean of $79.7 \%$ of children ate potatoes weekly or more often. A higher proportion of the older children $(P<0 \cdot 001)$, girls $(P<0 \cdot 001)$ and high FAS children $(P<0 \cdot 001)$, and a lower 
Table 2 Percentage compliance with the Greenlandic diet recommendations among students ( $n$ 2462) aged 11 to 17 years, (Greenland) Health Behaviour in School-aged Children (HBSC) survey, 2006

\begin{tabular}{|c|c|c|c|c|c|c|c|c|c|c|c|}
\hline & $\begin{array}{c}\text { Diet } \\
\text { variation* }\end{array}$ & $\begin{array}{l}\text { Intake of } \\
\text { marine } \\
\text { mammalst }\end{array}$ & $\begin{array}{c}\text { Intake of local } \\
\text { terrestrial animals } \\
\text { and birds }\end{array}$ & $\begin{array}{l}\text { Fish at least } \\
\text { once weekly }\end{array}$ & Daily fruit & $\begin{array}{c}\text { Daily } \\
\text { vegetables }\end{array}$ & $\begin{array}{l}\text { Potatoes } \\
\text { weekly or } \\
\text { more often }\end{array}$ & $\begin{array}{l}\text { Candy } \\
\text { weekly or } \\
\text { less often }\end{array}$ & $\begin{array}{l}\text { Soft drinks } \\
\text { weekly or } \\
\text { less often }\end{array}$ & $\begin{array}{c}\text { Breakfast all } \\
\text { weekdays }\end{array}$ & $\begin{array}{l}\text { Precooked dinners } \\
\text { less than four times } \\
\text { weekly }\end{array}$ \\
\hline All & $87 \cdot 0$ & $31 \cdot 6$ & $37 \cdot 1$ & $31 \cdot 8$ & $14 \cdot 3$ & $38 \cdot 9$ & $79 \cdot 7$ & $14 \cdot 7$ & $18 \cdot 6$ & $58 \cdot 6$ & $83 \cdot 4$ \\
\hline $\begin{array}{l}11-12 \text { years } \\
13-14 \text { years } \\
15-17 \text { years }\end{array}$ & $\begin{array}{c}84 \cdot 3 \\
85.6 \\
92 \cdot 0 \\
P<0.001\end{array}$ & $\begin{array}{c}40 \cdot 2 \\
30 \cdot 5 \\
22 \cdot 8 \\
P<0.001\end{array}$ & $\begin{array}{c}39 \cdot 4 \\
36 \cdot 3 \\
31 \cdot 1 \\
P<0 \cdot 001\end{array}$ & $\begin{array}{c}38 \cdot 1 \\
33 \cdot 0 \\
23 \cdot 0 \\
P<0.001\end{array}$ & $\begin{array}{c}18 \cdot 3 \\
13 \cdot 3 \\
10 \cdot 7 \\
P<0.001\end{array}$ & $\begin{array}{c}41 \cdot 5 \\
37 \cdot 8 \\
37 \cdot 5 \\
P=0 \cdot 2\end{array}$ & $\begin{array}{c}76.0 \\
78.9 \\
84 \cdot 8 \\
P<0.001\end{array}$ & $\begin{array}{c}15 \cdot 6 \\
15 \cdot 0 \\
12 \cdot 5 \\
P=0 \cdot 3\end{array}$ & $\begin{array}{c}22 \cdot 5 \\
16 \cdot 5 \\
16 \cdot 6 \\
P=0.003\end{array}$ & $\begin{array}{c}64 \cdot 4 \\
61 \cdot 4 \\
48 \cdot 5 \\
P<0 \cdot 001\end{array}$ & $\begin{array}{c}84 \cdot 4 \\
82 \cdot 5 \\
83 \cdot 7 \\
P=0.6\end{array}$ \\
\hline $\begin{array}{l}\text { Boys } \\
\text { Girls }\end{array}$ & $\begin{array}{c}85 \cdot 7 \\
88 \cdot 2 \\
P=0.07\end{array}$ & $\begin{array}{c}34 \cdot 0 \\
29 \cdot 3 \\
P=0 \cdot 01\end{array}$ & $\begin{array}{c}38.9 \\
35.4 \\
P=0.09\end{array}$ & $\begin{array}{c}33 \cdot 2 \\
30 \cdot 3 \\
P=0 \cdot 1\end{array}$ & $\begin{array}{c}13 \cdot 5 \\
15 \cdot 0 \\
P=0 \cdot 3\end{array}$ & $\begin{array}{c}34 \cdot 7 \\
42 \cdot 9 \\
P<0 \cdot 001\end{array}$ & $\begin{array}{c}76 \cdot 6 \\
82 \cdot 7 \\
P<0.001\end{array}$ & $\begin{array}{c}15 \cdot 5 \\
13 \cdot 9 \\
P=0 \cdot 3\end{array}$ & $\begin{array}{c}16 \cdot 7 \\
20 \cdot 4 \\
P=0 \cdot 02\end{array}$ & $\begin{array}{c}58 \cdot 2 \\
59 \cdot 0 \\
P=0.7\end{array}$ & $\begin{array}{c}83 \cdot 1 \\
83 \cdot 6 \\
P=0 \cdot 8\end{array}$ \\
\hline $\begin{array}{l}\text { Low FAS } \\
\text { Medium FAS } \\
\text { High FAS }\end{array}$ & $\begin{array}{c}84.0 \\
83.8 \\
89.6 \\
P<0.001\end{array}$ & $\begin{array}{c}41.6 \\
35.0 \\
26.9 \\
P<0.001\end{array}$ & $\begin{array}{c}33 \cdot 2 \\
36 \cdot 3 \\
40 \cdot 0 \\
P=0.04\end{array}$ & $\begin{array}{c}36 \cdot 2 \\
34 \cdot 3 \\
29 \cdot 8 \\
P<0.001\end{array}$ & $\begin{array}{c}12 \cdot 6 \\
12 \cdot 0 \\
15 \cdot 9 \\
P=0 \cdot 07\end{array}$ & $\begin{array}{c}31 \cdot 4 \\
40 \cdot 3 \\
39 \cdot 6 \\
P=0.006\end{array}$ & $\begin{array}{c}74.7 \\
77 \cdot 0 \\
84 \cdot 7 \\
P<0.001\end{array}$ & $\begin{array}{c}18 \cdot 1 \\
16 \cdot 0 \\
12 \cdot 6 \\
P=0 \cdot 02\end{array}$ & $\begin{array}{c}23.2 \\
18 \cdot 1 \\
17.9 \\
P=0.05\end{array}$ & $\begin{array}{c}52 \cdot 7 \\
54 \cdot 4 \\
64 \cdot 2 \\
P<0 \cdot 001\end{array}$ & $\begin{array}{c}81 \cdot 9 \\
83 \cdot 4 \\
83 \cdot 1 \\
P=0.6\end{array}$ \\
\hline $\begin{array}{l}\text { Villages } \\
\text { Cities } \\
\text { Capital }\end{array}$ & $\begin{array}{c}77 \cdot 1 \\
87 \cdot 2 \\
94 \cdot 9 \\
P<0 \cdot 001\end{array}$ & $\begin{array}{c}34 \cdot 1 \\
24.5 \\
12 \cdot 3 \\
P<0.001\end{array}$ & $\begin{array}{c}37 \cdot 0 \\
37 \cdot 3 \\
36 \cdot 7 \\
P=1 \cdot 0\end{array}$ & $\begin{array}{c}42 \cdot 2 \\
31.6 \\
23 \cdot 3 \\
P<0.001\end{array}$ & $\begin{array}{c}12 \cdot 1 \\
12 \cdot 8 \\
19 \cdot 7 \\
P<0 \cdot 001\end{array}$ & $\begin{array}{c}31 \cdot 9 \\
41 \cdot 7 \\
37 \cdot 8 \\
P=0.004\end{array}$ & $\begin{array}{c}67 \cdot 6 \\
81 \cdot 4 \\
86 \cdot 5 \\
P<0.001\end{array}$ & $\begin{array}{c}14 \cdot 5 \\
16 \cdot 4 \\
10 \cdot 5 \\
P=0.006\end{array}$ & $\begin{array}{c}17 \cdot 6 \\
19 \cdot 2 \\
17 \cdot 8 \\
P=0 \cdot 6\end{array}$ & $\begin{array}{c}45 \cdot 7 \\
59 \cdot 2 \\
69 \cdot 4 \\
P<0 \cdot 001\end{array}$ & $\begin{array}{c}18 \cdot 5 \\
17 \cdot 2 \\
13 \cdot 2 \\
P=0.06\end{array}$ \\
\hline
\end{tabular}

FAS, Family Affluence Scale.

Defined as less than four meals per week including seal meat, or four including wild fowl, or four including whale meat.

Defined as eating local terrestrial animals (reindeer, musk ox or lamb) at least once weekly or birds between one and three times weekly. 
proportion of village children $(P<0 \cdot 001)$, had a weekly or higher intake.

Candy weekly or less often. While a mean of $14.7 \%$ ate candy weekly or less, a lower percentage of low FAS children $(P=0 \cdot 02)$ and children in the capital $(P=0 \cdot 006)$ did so.

Soft drinks weekly or less often. A mean of $18.6 \%$ of children drank soft drinks weekly or less. The youngest children $(P=0 \cdot 003)$, girls $(P=0 \cdot 02)$ and low FAS children $(P=0 \cdot 05)$ had a higher percentage with a low intake.

Breakfast all weekdays. A mean of 58.6\% ate breakfast all days of school, a higher proportion among the youngest children $(P<0 \cdot 001)$, but a lower proportion of low FAS children $(P<0 \cdot 001)$ and children in villages $(P<0 \cdot 001)$.

Precooked dinners less than four times weekly. A mean of $83.4 \%$ ate precooked dinners less than four times weekly. There were no gender or age differences.

\section{Multiple logistic regressions}

In most cases, the associations between dietary intake and place of living were graded from the capital to villages with towns in between, also after adjusting for age, gender and FAS (Table 3).

Diet variation. The unadjusted OR for diet variation was 0.18 in villages $(P<0 \cdot 001)$, with only minor changes after adjustment for age, gender and FAS.

Intake of marine mammals. The unadjusted OR for recommended intake in village children was $3 \cdot 71$ $(P<0 \cdot 001)$, with only minor changes after adjustment for age, gender and FAS.

Intake of local terrestrial animals and birds. This showed no association with place of living.

Fish at least once weekly. Village children had a higher intake $(\mathrm{OR}=2 \cdot 40, P<0 \cdot 001)$, which remained almost unchanged after adjustment.

Table 3 Odds of complying with the Greenlandic diet recommendations by place of living among students ( $n 2462)$ aged 11 to 17 years, (Greenland) Health Behaviour in School-aged Children (HBSC) survey, 2006

\begin{tabular}{|c|c|c|c|c|c|c|c|}
\hline & & \multicolumn{2}{|c|}{ Model 1} & \multicolumn{2}{|c|}{ Model 2} & \multicolumn{2}{|c|}{ Model 3} \\
\hline & & OR & $95 \% \mathrm{Cl}$ & OR & $95 \% \mathrm{Cl}$ & OR & $95 \% \mathrm{Cl}$ \\
\hline \multirow[t]{3}{*}{ Diet variation* } & Capital (reference) & $1 \cdot 00$ & & $1 \cdot 00$ & & $1 \cdot 00$ & \\
\hline & Towns & 0.37 & $0.24,0.56$ & 0.33 & $0.21,0.51$ & $0 \cdot 40$ & $0.26,0.63$ \\
\hline & Villages & $0 \cdot 18$ & $0 \cdot 12,0 \cdot 28$ & 0.19 & $0.12,0.29$ & 0.22 & $0.13,0.35$ \\
\hline \multirow{3}{*}{ Intake of marine mammalst } & Capital (reference) & 1.00 & & 1.00 & & 1.00 & \\
\hline & Towns & $2 \cdot 33$ & $1 \cdot 74,3 \cdot 12$ & $2 \cdot 50$ & $1 \cdot 86,3 \cdot 37$ & $2 \cdot 41$ & $1 \cdot 75,3 \cdot 33$ \\
\hline & Villages & $3 \cdot 71$ & $2 \cdot 67,5 \cdot 14$ & $3 \cdot 73$ & $2 \cdot 67,5 \cdot 22$ & $3 \cdot 62$ & $2 \cdot 51,5 \cdot 22$ \\
\hline \multirow[t]{3}{*}{ Intake of local terrestrial animals and birdsł } & Capital (reference) & 1.00 & & $1 \cdot 00$ & & $1 \cdot 00$ & \\
\hline & Towns & $1 \cdot 01$ & $0 \cdot 82,1 \cdot 26$ & $1 \cdot 05$ & $0 \cdot 85,1 \cdot 31$ & $1 \cdot 13$ & $0.89,1.43$ \\
\hline & Villages & 0.99 & $0.76,1 \cdot 29$ & 0.94 & $0.72,1.25$ & 1.09 & $0.81,1.46$ \\
\hline \multirow[t]{3}{*}{ Fish at least once weekly } & Capital (reference) & $1 \cdot 00$ & & $1 \cdot 00$ & & $1 \cdot 00$ & \\
\hline & Towns & $1 \cdot 52$ & $1 \cdot 20,1 \cdot 92$ & $1 \cdot 61$ & $1 \cdot 28,2 \cdot 06$ & 1.59 & $1 \cdot 23,2 \cdot 06$ \\
\hline & Villages & $2 \cdot 40$ & $1 \cdot 83,3 \cdot 16$ & $2 \cdot 29$ & $1 \cdot 74,3.03$ & $2 \cdot 30$ & $1 \cdot 69,3 \cdot 12$ \\
\hline \multirow[t]{3}{*}{ Daily fruit } & Capital (reference) & $1 \cdot 00$ & & $1 \cdot 00$ & & $1 \cdot 00$ & \\
\hline & Towns & 0.60 & $0.45,0.79$ & 0.61 & $0.46,0.81$ & 0.64 & $0.47,0.87$ \\
\hline & Villages & 0.56 & $0 \cdot 39,0.81$ & 0.54 & $0.38,0.79$ & 0.59 & $0.39,0.90$ \\
\hline \multirow[t]{3}{*}{ Daily vegetables } & Capital (reference) & $1 \cdot 00$ & & $1 \cdot 00$ & & $1 \cdot 00$ & \\
\hline & Towns & $1 \cdot 18$ & $0.95,1.45$ & $1 \cdot 18$ & $0.96,1.45$ & $1 \cdot 19$ & $0.94,1.50$ \\
\hline & Villages & 0.79 & $0.59,1 \cdot 01$ & $0 \cdot 76$ & $0.58,1.00$ & $0 \cdot 81$ & $0.60,1.09$ \\
\hline \multirow[t]{3}{*}{ Potatoes weekly or more often } & Capital (reference) & $1 \cdot 00$ & & $1 \cdot 00$ & & $1 \cdot 00$ & \\
\hline & Towns & 0.68 & $0.51,0.91$ & 0.65 & $0.48,0.87$ & 0.77 & $0.56,1.06$ \\
\hline & Villages & 0.33 & $0 \cdot 24,0 \cdot 45$ & 0.33 & $0.24,0.46$ & 0.40 & $0.26,0.54$ \\
\hline \multirow[t]{3}{*}{ Candy weekly or less often } & Capital (reference) & $1 \cdot 00$ & & $1 \cdot 00$ & & 1.00 & \\
\hline & Towns & $1 \cdot 68$ & $1 \cdot 22,2 \cdot 31$ & $1 \cdot 79$ & $1 \cdot 29,2 \cdot 48$ & $1 \cdot 65$ & $1 \cdot 15,2 \cdot 35$ \\
\hline & Villages & $1 \cdot 45$ & $1 \cdot 00,2 \cdot 14$ & $1 \cdot 40$ & $0.95,2.08$ & $1 \cdot 23$ & $0.80,1.89$ \\
\hline \multirow[t]{3}{*}{ Soft drinks weekly or less often } & Capital (reference) & $1 \cdot 00$ & & $1 \cdot 00$ & & $1 \cdot 00$ & \\
\hline & Towns & $1 \cdot 10$ & $0 \cdot 84,1 \cdot 43$ & $1 \cdot 11$ & $0 \cdot 85,1 \cdot 45$ & $1 \cdot 02$ & $0.77,1.36$ \\
\hline & Villages & 0.98 & $0 \cdot 71,1 \cdot 37$ & 0.98 & $0 \cdot 70,1 \cdot 37$ & 0.83 & $0.57,1.19$ \\
\hline \multirow[t]{3}{*}{ Breakfast all weekdays } & Capital (reference) & $1 \cdot 00$ & & $1 \cdot 00$ & & $1 \cdot 00$ & \\
\hline & Towns & 0.64 & $0.51,0.81$ & 0.68 & $0.53,0.86$ & $0 \cdot 82$ & $0.63,1.06$ \\
\hline & Villages & 0.37 & $0.28,0.49$ & 0.32 & $0.24,0.43$ & 0.40 & $0.29,0.55$ \\
\hline \multirow[t]{3}{*}{ Precooked dinners less than four times weekly } & Capital (reference) & $1 \cdot 00$ & & $1 \cdot 00$ & & $1 \cdot 00$ & \\
\hline & Towns & $1 \cdot 40$ & $1 \cdot 02,1 \cdot 84$ & $1 \cdot 12$ & $0.89,1.51$ & $1 \cdot 44$ & $1 \cdot 10,1.99$ \\
\hline & Villages & $1 \cdot 49$ & $1 \cdot 05,2 \cdot 12$ & $1 \cdot 04$ & $0.78,1 \cdot 39$ & $1 \cdot 49$ & $1 \cdot 01,2 \cdot 20$ \\
\hline
\end{tabular}

Model 1, crude model; Model 2, adjusted for age and gender; Model 3, adjusted for age, gender and family affluence.

*Defined as less than four meals per week including seal meat, or four including wild fowl, or four including whale meat.

tDefined as eating marine mammals (seal or whale) between one and three times weekly.

fDefined as eating local terrestrial animals (reindeer, musk ox or lamb) at least once weekly or birds between one and three times weekly. 
Daily fruit. Fruit intake was lowest in villages $(\mathrm{OR}=0.56$, $P=0 \cdot 001$ ), with small changes after adjustment.

Daily vegetables. Daily vegetable intake was positively associated with living in the capital $(P<0 \cdot 001)$.

Potatoes weekly or more often. The unadjusted OR for eating potatoes was lower $(0.33, P<0.001)$ in village children, remaining almost unchanged after adjustment.

Candy weekly or less often. A positive association was found between living in a town and a high candy intake $(\mathrm{OR}=1 \cdot 68, P=0 \cdot 006)$.

Soft drinks weekly or less often. Intake of soft drinks showed no association with place of living.

Breakfast all weekdays. A negative association between living in a village and eating breakfast was found $(\mathrm{OR}=$ $0 \cdot 37, P<0 \cdot 001$, which was unchanged after adjustment.

Precooked dinners less than four times weekly. A nonsignificant association was found between living in a village and eating precooked dinners $(\mathrm{OR}=1 \cdot 49, P=0 \cdot 06)$.

\section{Stratification for gender, age group and family affluence}

When running Model 1 stratified for gender, age group and FAS, few significant changes were found (not shown). None of them changed the above-described general patterns.

\section{Discussion}

The results of the present study revealed that the proportion of children eating according to guidelines varied highly depending on the food item in question; from below $20 \%$ for eating fruits daily and eating candy or drinking soft drinks weekly or less to $87 \%$ of children having variation in intake of local meats. However, the compliance with the dietary guidelines differed by age group, gender, family affluence and place of living.

In general, the younger children more often followed the guidelines. A lower proportion of the oldest children ate breakfast every school day, ate fruit daily and ate marine mammals one to three times weekly, while a higher proportion drank soft drinks more often than weekly. Due to the less frequent intake of marine mammals, the oldest children had the highest proportion with variation in the intake of local meat.

More boys seemed to prefer eating local meats than girls, while more girls ate vegetables. The same gender differences in food choices have been revealed in other studies in Greenland among both adolescents and adults ${ }^{(9,18)}$ as well as in European children ${ }^{(14,19)}$. The differences, therefore, seem to reflect a general pattern regarding food preferences between genders.

The differences in compliance with guidelines were to a high extent independent of the nutritional value of the food items, while a graded association between compliance with guidelines and place of living was revealed for many food items. The largest differences between intakes of food items were found between children living in villages and children living in the capital. The general finding was that more children in villages ate local food items often while children in the capital had a higher intake of imported food. The same relationships between habitation and food intake have been described previously among adolescents and adults. The intake of traditional foods was found to be highest in north Greenland and in the remote areas, whereas a higher intake of terrestrial animals, fruits and vegetables was found in larger cities and the capital ${ }^{(6,18)}$. The majority of adults in villages (about $80 \%$ ) eat a main course of own supply at least weekly, compared with only about $20 \%$ in the capital ${ }^{(9)}$. The high intake of local foods in village children contributed to the higher compliance with guidelines on seal, whale and fish intake, but also to the lower diet variation found for these children.

Lack of tradition and the lower family affluence generally found in villages might explain in part why less than $60 \%$ of children are eating breakfast on all schooldays and why the proportion eating breakfast daily is lowest in village children. Eating regular meals is not a tradition in Greenland and still fewer families in villages eat at specific times during the day ${ }^{(10)}$. In European countries a lower proportion of low affluence children were found to eat breakfast daily ${ }^{(14)}$. A decline in eating breakfast with increasing age was also found in our Greenlandic children. A decline in breakfast consumption with increasing age was a general finding among European children, too ${ }^{(14)}$. This pattern is thought to reflect a higher degree of independence and a less family-oriented lifestyle and thereby dietary habits when growing into adolescence.

In many industrialized countries, food distribution is dominated by larger businesses. Local shops in poorer areas are often over-priced and low on choice and quality $^{(1)}$. Among adolescents in Arctic Canada cost and availability were found to be the major barriers to healthy eating ${ }^{(20)}$. Even if some general subsidization of food availability and costs exists, trade dynamics might have a potential negative impact on the supply of healthy foods in Greenland as well as in other countries.

Compared with European schoolchildren, Greenland has the lowest proportion of schoolchildren with a daily intake of fruit ${ }^{(14)}$ and data revealed that both low FAS and living in a village were associated with a low fruit intake. That fruit is an imported food item cannot explain the finding, because regarding the intake of both soft drinks and sweets, a high proportion of Greenlandic children, 
independent of the place of living, have a daily intake comparable to that of children in other European and North American populations ${ }^{(14)}$.

It is known that less fruits are consumed in less affluent municipalities in Greenland ${ }^{(6)}$. Even if common fruits are sold in most habitations today, the availability (and quality) is still higher and the cost of fruits is lower in cities and the capital. Differences in availability and affordability contribute to pass on the tradition of low fruit intake to the child generation. The associations between fruit intake, availability and affluence are not a unique Greenlandic finding. In several European countries, low family affluence is associated with a low intake of fruits among children ${ }^{(14)}$; and in the USA low availability of fruits in the home was associated with low fruit intake ${ }^{(21)}$.

The questionnaire used in the present study provides data on food frequency intake, but not on quantity. It is therefore inappropriate to use it for calculation of energy and micronutrient distribution in the diet. However, despite its limitations, the study provided useful knowledge on compliance with the national dietary guidelines for Greenlandic children.

The study's results show that there is potential for improving schoolchildren's compliance with the national dietary guidelines in Greenland. Despite the high intake of local foods taken as a whole, children in villages and low affluent children were less likely to comply with the national recommendations. These groups had the lowest level of variation in intake of local meats, fewer of them ate breakfast daily, fruits daily and potatoes often, and at the same time a high proportion of them had a frequent intake of sweets and soft drinks. The study indicates that factors such as local availability and cost are important to the use of both imported and local foods; and that a complex relationship between compliance with dietary recommendations, family affluence, household food traditions and local availability of foods exists. The study's findings should be taken into consideration when promoting the national guidelines in the future.

\section{Acknowledgements}

The paper has been funded by a grant from the NunaFond, no. 323/05. The authors have no conflicts of interest. Both authors collected the data, B.N. conducted the analysis and both authors contributed to the manuscript. The study is based on data from the HBSC Greenland school surveys, started by Johan Michael Pedersen in 1994. Since 2005, B.N. from the District Medical Clinic in Nuuk has been responsible for the study. HBSC Greenland is contributing to the Health Behaviour in School-aged Children (HBSC) study that is a cross-national research survey conducted in collaboration with the WHO Regional Office for Europe by international coordinator Candace Currie, Health Education
Board, University of Edinburgh and databank manager Oddrun Samdal, University of Bergen, Norway.

\section{References}

1. World Health Organization (2007) European Action Plan for Food and Nutrition Policy 2007-2012. Copenhagen: WHO Regional Office for Europe.

2. Young TK \& Bjerregaard P (editors) (2008) Health Transitions in Arctic Populations. Toronto: University of Toronto Press.

3. Schnohr C, Sørensen TIA \& Niclasen BV-L (2005) Changes since 1980 in body mass index and the prevalence of overweight among inschooling children in Nuuk, Greenland. Int J Circumpolar Health 64, 157-162.

4. Niclasen BV-L, Petzold MG \& Schnohr C (2007) Overweight and obesity at school entry as predictor of overweight in adolescence in an Arctic child population. Eur J Public Health 17, 17-20.

5. Schnohr C, Petersen JH \& Niclasen BV-L (2008) Onset of overweight in Nuuk, Greenland: a retrospective cohort study of children from 1973 to 1992. Obesity (Silver Spring) 16, 2734-2738.

6. Hansen JC, Deutch B \& Odland JØ (2008) Dietary Transition and Contaminants in the Arctic: Emphasis on Greenland. Circumpolar Health Supplements no. 2. Oulo: International Association of Circumpolar Health Publishers.

7. Deutch B, Dyerberg J, Pedersen HS et al. (2006) Dietary composition and contaminants in north Greenland, in the 1970s and 2004. Sci Total Environ 370, 372-381.

8. Nordic Council of Ministers (2004) Nutrition Recommendations - Integrating Nutrition and Physical Activity. Nord: 13. Copenhagen: Nordic Council of Ministers.

9. Bjerregaard P \& Dahl-Petersen I (editors) (2008) Levevilkår, livsstil og sundhed $i$ Gronland 2005-2007 (Living Conditions, Lifestyle and Health in Greenland 2005-2007). Copenhagen: National Institute of Public Health.

10. Bjerregaard P, Curtis T, Senderovitz F et al. (1995) Levevilkår, livsstil og helbred $i$ Grønland (Welfare, Lifestyle, and Health in Greenland). Copenhagen: Danish Institute for Clinical Epidemiology.

11. Johansen P, Muir D, Asmund G et al. (2004) Human exposure to contaminants in the traditional Greenland diet. Sci Total Environ 331, 189-206.

12. Bjerregaard P (2004) Folkesundhed $i$ Grønland (Public Health in Greenland). Report no. 1/2004. Nuuk: Home Rule Government.

13. Home Rule Government (2007) Inuuneritta - Folkesundhedsprogram, Landsstyrets strategier og målsatninger for folkesundheden 2007-2012 (Public Health Programme, Strategies and Goals from 2007 to 2012). Nuuk: Home Rule Government.

14. Currie C, Gabhainn SN, Godeau E et al. (2008) Inequalities in Young People's Health. HBSC International Report from the 2005/2006 Survey. Copenhagen: WHO Regional Office for Europe.

15. Niclasen B, Løngaard K, Laursen LK et al. (2007) Sundhed på toppen (Health on the Top of the World). Nuuk: Home Rule Government.

16. Vereecken CA \& Maes L (2003) A Belgian study on the reliability and relative validity of the Health Behaviour in School-Aged Children food-frequency questionnaire. Public Health Nutr 6, 581-588.

17. Currie C, Molcho M, Boyce W et al. (2008) Researching health inequalities in adolescents: the development of the Health Behaviour in School-aged Children (HBSC) Family Affluence Scale. Soc Sci Med 66, 1429-1436. 
18. Curtis T, Larsen HB, Helweg-Larsen K et al. (2006) Unges trivsel i Grønland 2004 (Well-being in Greenlandic adolescents in 2004). Inussuk Arktisk Forskningsjournal 1, 1-117.

19. Johnson B \& Hackett AF (2007) Trends in fruit, vegetable and salad intakes in 9-10-year-old schoolchildren living in Liverpool, 2000-2005. Public Health Nutr 10, 252-255.
20. Lambden J, Receveur O, Marshall J et al. (2006) Traditional and market food access in Arctic Canada is affected by economic factors. Int J Circumpolar Health 65, 331-340.

21. Ard JD, Fitzpatrick S, Desmond RA et al. (2007) The impact of cost on the availability of fruits and vegetables in the homes of schoolchildren in Birmingham, Alabama. Am J Public Health 97, 367-372. 